\title{
Action of Propranolol on Left Ventricular Contraction in Aortic Stenosis When a Fall in Heart Rate is Prevented by Atropine
}

\author{
JOHN HAMER AND JAMES FLEMING
}

From the Department of Cardiology, St. Bartholomew's Hospital, London E.C.1

\begin{abstract}
A previous study of the changes in left ventricular pressure and volume produced by propranolol in patients with severe aortic stenosis (Hamer and Fleming, 1967) indicated a reduction in the velocity of myocardial contraction after this drug. However, a major action of propranolol is to reduce the heart rate, and as bradycardia may be associated with a reduction in the velocity of contraction it was not clear whether we were producing a true effect on contractility other than that which might be expected from the slower rate. In the present study the bradycardia that follows the administration of propranolol has been prevented by giving a large dose of atropine. Any changes in the force or velocity of contraction of the left ventricular muscle under these circumstances can be attributed to a direct action of propranolol on the myocardium.
\end{abstract}

\section{METHODS}

Left ventricular pressure and volume were measured before the administration of any drug, and the measurements were repeated after the administration of propranolol and atropine. The studies were carried out as part of the routine catheterization in 6 patients being assessed for aortic valve replacement. In all cases there was severe obstruction at the aortic valve, though a minor degree of aortic incompetence was present in one subject.

Cardiac catheterization was performed from the right saphenous vein without premedication. Pressures were measured with a P23Db Statham strain gauge and a N.E.P. photographic recorder at a paper speed of 80 $\mathrm{mm}$./sec., using the sternal angle as the zero reference level. Cardiac output was measured by the indicator dilution technique using a Gilford cuvette and indocyanine green. The indicator dilution curves were calibrated by the dynamic method (Shinebourne, Fleming, and Hamer, 1967). After catheterization of the right heart, a Brockenbrough catheter was inserted and the left ventricle was entered by transseptal puncture. The

Received March 13, 1969. dye was injected into the left ventricle and a No. 6 Teflon Gensini catheter was placed in the right femoral artery by the percutaneous method to record the indicator dilution curves. The Gensini catheter was advanced to the ascending aorta about $1 \mathrm{~cm}$. above the aortic valve and the pressure gradient at the aortic valve and the left ventricular diastolic pressure recorded. A chromel-constantin thermocouple wire (Watson and Fleming, 1968) was inserted into the aortic catheter until it just protruded from the tip. Multiple injections of between 5 and $10 \mathrm{ml}$. of ice-cold saline were given into the left ventricle, and the thermodilution curves from the aortic thermocouple were recorded photographically. $5 \mathrm{mg}$. propranolol and $2.4 \mathrm{mg}$. atropine were injected into the left ventricle in 1 minute. After 10 minutes the thermodilution curves were repeated. The thermocouple was then withdrawn and further pressure measurements and indicator dilution curves obtained. The thermodilution curves and the measurements of cardiac output by indicator dilution were performed within a 10-minute period without evident change in the state of the patient.

The ratio between the steps of the thermodilution curve was measured, beginning from the fourth beat after the appearance of the indicator and continuing until accurate measurement became difficult. If an ectopic beat occurred no measurements were made until there had been two subsequent normal beats. Up to 5 measurements were made on each curve, and from 3 to 6 curves were obtained in each part of the study in each subject, so that the value for the thermodilution ratio (r) used to calculate the left ventricular end-diastolic volume was the mean of from 7 to 20 observations. The ratio is a measure of the degree of emptying of the ventricle, and the end-diastolic volume is obtained by dividing the stroke volume, calculated from the cardiac output and heart rate, by the fraction 1-r.

Left ventricular systolic time was measured from amplified records of left ventricular diastolic pressure on a scale of $10 \mathrm{~mm} . \mathrm{Hg} / \mathrm{cm}$. and a paper speed of $75 \mathrm{~cm}$./ sec. Left ventricular ejection time was measured from simultaneous records of aortic and left ventricular pres670 
speed. Pressure-time per minute, that is the tensiontime index of Sarnoff et al. (1958), was measured as the product of mean ventricular systolic pressure $(\mathrm{mm} . \mathbf{H g})$, the duration of ventricular systole (sec.), and the heart rate (per min.). Other indices of ventricular work were calculated on the assumption that the left ventricle was a spherical chamber with a constant rate of emptying. From the Laplace relation for a sphere, the force per unit of circumference $(f)$ is, half the product of the pressure and the radius $\left(f=\frac{1}{2} \mathrm{Pr}\right)$. The total force at the circumference $(F)$ is given by $F=\frac{1}{2} \operatorname{Pr} \times 2 \pi r=\pi P \times r^{2}$, that is the product of the pressure and the cross-sectional area $\left(\pi r^{2}\right)$. Mean systolic force in the ventricular wall was therefore determined as the product of the mean ventricular systolic pressure $(\mathrm{mm}$. $\mathbf{H g}$ ) and the mean crosssectional area $\left(\mathrm{cm}^{2}{ }^{2}\right.$ ). Force-time per minute was estimated as the product of mean systolic force ( $\mathrm{mm}$. $\mathrm{Hg} \times \mathrm{cm}^{2}{ }^{2}$ ), the duration of ventricular systole (sec.), and the heart rate (per min.). We also calculated the mean ventricular ejection rate (ml./sec.) from the stroke volume and ejection time. The mean circumferential shortening rate was obtained from the ejection time and the difference between end-diastolic and end-systolic circumference assuming a spherical ventricle, and was expressed in $\mathrm{cm} . / \mathrm{sec}$. and in terms of change in the mean circumference per sec.

TABLE I

CLINICAL ASSESSMENT AND CATHETERIZATION FINDINGS

\begin{tabular}{c|c|c|c|c|c|c}
\hline $\begin{array}{c}\text { Case } \\
\text { No. }\end{array}$ & $\begin{array}{c}\text { Age } \\
\text { (yr.) }\end{array}$ & Sex & $\begin{array}{c}\text { Degree } \\
\text { of } \\
\text { oortic } \\
\text { incom- } \\
\text { petence } \\
(0-4)\end{array}$ & $\begin{array}{c}\text { Body } \\
\text { surface } \\
\text { area } \\
\left(\mathrm{m} .{ }^{2}\right)\end{array}$ & $\begin{array}{c}\text { Cardiac } \\
\text { output } \\
(1 . / \mathrm{min} .)\end{array}$ & $\begin{array}{c}\text { Aortic } \\
\text { valve } \\
\text { area } \\
\left(\mathrm{cm} .^{2}\right)\end{array}$ \\
\hline 1 & 56 & $\mathrm{M}$ & 0 & 1.96 & 3.5 & \\
\hline 2 & 40 & $\mathrm{M}$ & 1 & 1.84 & 3.0 & 0.4 \\
3 & 58 & $\mathrm{~F}$ & 0 & 1.83 & 6.6 & 0.6 \\
4 & 49 & $\mathrm{~F}$ & 0 & 1.58 & 3.4 & 0.4 \\
5 & 55 & $\mathrm{M}$ & 0 & 1.75 & 4.7 & 0.4 \\
6 & 49 & $\mathrm{M}$ & 0 & 1.94 & 5.4 & 0.7 \\
\hline
\end{tabular}

TABLE II

HAEMODYNAMIC MEASUREMENTS BEFORE AND AFTER PROPRANOLOL AND ATROPINE

\begin{tabular}{|c|c|c|c|c|c|c|c|c|c|}
\hline $\begin{array}{l}\text { Case } \\
\text { No. }\end{array}$ & & $\begin{array}{c}\text { LV systolic } \\
\text { pressure } \\
\text { (mm. Hg) }\end{array}$ & $\begin{array}{l}\mathbf{L V} \\
\mathbf{p r} \\
(\mathbf{m} \\
\mathbf{z}\end{array}$ & $\begin{array}{l}\text { olic } \\
\text { re } \\
\text { (g) } \\
\text { a }\end{array}$ & $\begin{array}{c}\text { PR interval } \\
\text { (sec.) }\end{array}$ & $\begin{array}{c}\text { Cardiac output } \\
(1 . / \mathrm{min} .)\end{array}$ & $\begin{array}{c}\text { Heart } \\
\text { rate/min. }\end{array}$ & $\begin{array}{l}\text { Stroke volume } \\
\text { (ml.) }\end{array}$ & $\begin{array}{c}\text { LV end- } \\
\text { diastolic } \\
\text { volume } \\
\text { (ml.) }\end{array}$ \\
\hline $\begin{array}{l}1 \\
2 \\
3 \\
4 \\
5 \\
6\end{array}$ & $\begin{array}{l}\text { Before } \\
\text { After } \\
\text { Before } \\
\text { After } \\
\text { Before } \\
\text { After } \\
\text { Before } \\
\text { After } \\
\text { Before } \\
\text { After } \\
\text { Before } \\
\text { After }\end{array}$ & $\begin{array}{l}185 \\
190 \\
170 \\
155 \\
240 \\
230 \\
195 \\
205 \\
270 \\
240 \\
180 \\
185\end{array}$ & $\begin{array}{r}-2 \\
2 \\
7 \\
0 \\
6 \\
6 \\
5 \\
5 \\
15 \\
10 \\
8 \\
5\end{array}$ & $\begin{array}{r}5 \\
7 \\
18 \\
10 \\
12 \\
14 \\
12 \\
10 \\
22 \\
25 \\
16 \\
10\end{array}$ & $\begin{array}{l}0.20 \\
0.21 \\
0.23 \\
0.23 \\
0.16 \\
0.18 \\
0.13 \\
0.14 \\
0.16 \\
0.18 \\
0.14 \\
0.15\end{array}$ & $\begin{array}{l}3.5 \\
2.6 \\
3.0 \\
3.0 \\
6 \cdot 6 \\
5 \cdot 7 \\
3.4 \\
3.4 \\
4.7 \\
3.7 \\
5 \cdot 4 \\
4.5\end{array}$ & $\begin{array}{l}79 \\
86 \\
71 \\
81 \\
81 \\
83 \\
81 \\
94 \\
98 \\
89 \\
72 \\
81\end{array}$ & $\begin{array}{l}45 \\
30 \\
42 \\
37 \\
82 \\
69 \\
42 \\
36 \\
48 \\
42 \\
75 \\
54\end{array}$ & $\begin{array}{l}170 \\
130 \\
205 \\
190 \\
195 \\
175 \\
125 \\
130 \\
155 \\
145 \\
300 \\
235\end{array}$ \\
\hline Mean & $\begin{array}{l}\text { Before } \\
\text { After }\end{array}$ & $\begin{array}{l}195 \\
200\end{array}$ & $\begin{array}{l}7 \\
5\end{array}$ & $\begin{array}{l}14 \\
13\end{array}$ & $\begin{array}{l}0.17 \\
0.18\end{array}$ & $\begin{array}{l}4 \cdot 4 \\
3 \cdot 8\end{array}$ & $\begin{array}{l}80 \\
85\end{array}$ & $\begin{array}{l}56 \\
45\end{array}$ & $\begin{array}{l}190 \\
180\end{array}$ \\
\hline
\end{tabular}
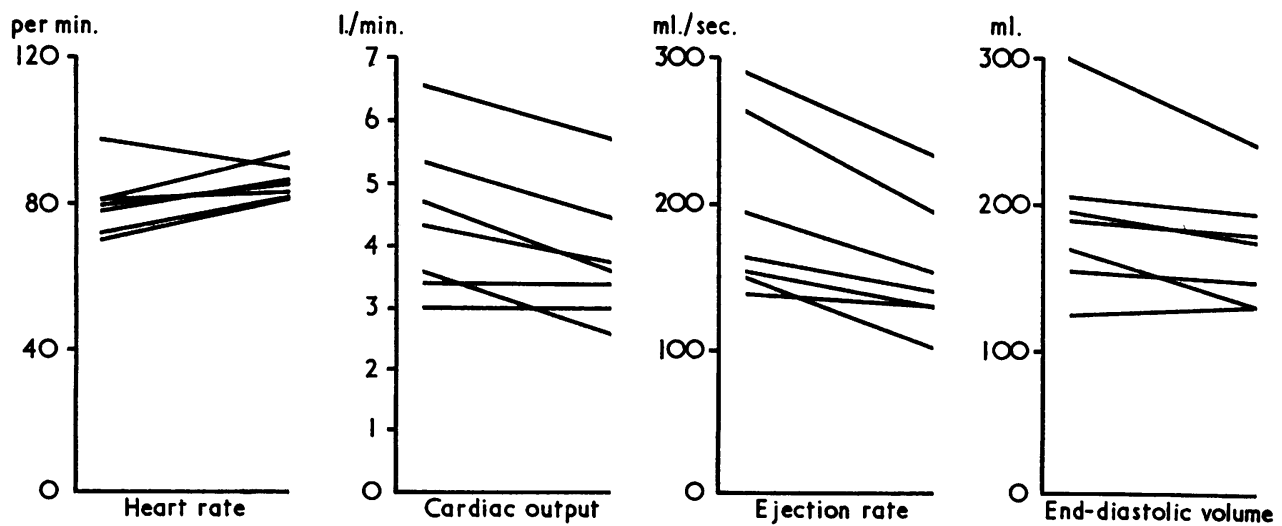

FIG. 1.-The change in heart rate, cardiac output, mean ejection rate, and end-diastolic volume of the left ventricle (measured by the thermodilution method) in 6 patients with aortic stenosis after propranolol $5 \mathrm{mg}$. and atropine $2.4 \mathrm{mg}$. The bradycardia usually produced by propranolol is prevented by atropine, but cardiac output and ejection rate are reduced. 


\section{RESULTS}

The cardiac catheterization findings confirmed the clinical diagnosis of severe aortic stenosis in each patient (Table I). The cardiac output was often below normal, the left ventricular systolic pressure was considerably raised, and some patients had a high left ventricular end-diastolic pressure. The similarity of the calculated aortic valve area before and after the drugs confirmed the accuracy of the pressure and flow measurements.

The combination of $5 \mathrm{mg}$. propranolol and $2 \cdot 4 \mathrm{mg}$. atropine led to a slight increase in heart rate in 5 of the 6 patients, the average rate rising from 80 to $85 / \mathrm{min}$. (Table II and Fig. 1). Cardiac output, measured by the indicator dilution technique, fell in 4 patients and was unchanged in the other 2 , giving a significant fall from 4.4 to $3.81 . / \mathrm{min}$. $(p<0.05)$ on average. Stroke volume was consistently reduced, the average falling from 56 to 45 $\mathrm{ml}$. $(\mathrm{p}<0.02)$. There was little change in left ventricular systolic or diastolic pressure, and though the $P-R$ interval was usually increased the change was only 0.01 or $0.02 \mathrm{sec}$.

The duration of left ventricular systole was little affected by the drugs, and there was no consistent change in ejection time. As might be expected under these circumstances, there was little alteration in pressure-time per minute. The mean systolic ejection rate, however, was consistently reduced, giving an average fall from 195 to $155 \mathrm{ml} . / \mathrm{sec}$. $(p>0.01)$.

The thermodilution ratio was consistently increased, from a mean of 0.70 to $0.73(p<0.02)$, indicating less complete emptying of the ventricle at each beat. The number and scatter of thermodilution measurements in each patient are shown in Table III. In 3 cases, the difference before and after the drugs was statistically significant. The trend was similar in the other 3 subjects, and the pooled results, expressed in terms of deviation from the mean of each patient, show a highly significant increase after propranolol and atropine. The

TABLE III

THERMODILUTION MEASUREMENTS BEFORE AND AFTER PROPRANOLOL AND ATROPINE

\begin{tabular}{|c|c|c|c|c|c|c|c|}
\hline Case No. & & No. of curves & No. of ratios & Mean ratio & SD & $\mathbf{t}$ & p \\
\hline 1 & \multirow{6}{*}{$\begin{array}{l}\text { Before } \\
\text { After } \\
\text { Before } \\
\text { After } \\
\text { Before } \\
\text { After } \\
\text { Before } \\
\text { After } \\
\text { Before } \\
\text { After } \\
\text { Before } \\
\text { After }\end{array}$} & \multirow[t]{6}{*}{5} & \multirow{6}{*}{$\begin{array}{r}16 \\
17 \\
20 \\
18 \\
8 \\
10 \\
11 \\
7 \\
10 \\
10 \\
9 \\
10\end{array}$} & \multirow{6}{*}{$\begin{array}{l}0.739 \\
0.769 \\
0.784 \\
0.803 \\
0.581 \\
0.604 \\
0.658 \\
0.720 \\
0.690 \\
0.713 \\
0.752 \\
0.767\end{array}$} & \multirow{6}{*}{$\begin{array}{l}0.027 \\
0.015 \\
0.017 \\
0.014 \\
0.018 \\
0.025 \\
0.029 \\
0.028 \\
0.042 \\
0.034 \\
0.019 \\
0.017\end{array}$} & $3 \cdot 8$ & $<0.001$ \\
\hline 2 & & & & & & 5.5 & $<0.001$ \\
\hline 3 & & & & & & 0.9 & $>0.3$ \\
\hline 4 & & & & & & $4 \cdot 2$ & $<0.001$ \\
\hline 5 & & & & & & $1 \cdot 3$ & $>0.2$ \\
\hline 6 & & & & & & 1.7 & $>0.05$ \\
\hline Total & & & 74 & & 0.026 & $6 \cdot 8$ & $<0.001$ \\
\hline & After & 26 & 72 & 0.728 & 0.022 & & \\
\hline
\end{tabular}

TABLE IV

VENTRICULAR FORCE AND VELOCITY MEASUREMENTS

\begin{tabular}{|c|c|c|c|c|c|c|c|c|c|c|}
\hline \multirow[t]{2}{*}{$\begin{array}{l}\text { Case } \\
\text { No. }\end{array}$} & & \multirow{2}{*}{$\begin{array}{c}\text { Systolic } \\
\text { time } \\
\text { (sec.) }\end{array}$} & \multirow{2}{*}{$\begin{array}{c}\text { Mean LV } \\
\text { systolic } \\
\text { pressure } \\
(\mathrm{mm} . \mathbf{H g})\end{array}$} & \multirow{2}{*}{$\begin{array}{l}\text { Pressure- } \\
\text { time } \\
\text { per min. } \\
\text { (mm. Hg } \\
\text { sec./min.) }\end{array}$} & \multirow{2}{*}{$\begin{array}{c}\text { Mean } \\
\text { systolic } \\
\text { force } \\
(\mathrm{mm} . \mathbf{H g} / \\
\left.\text { cm. }^{2}\right)\end{array}$} & \multirow{2}{*}{$\begin{array}{c}\text { Force-time } \\
\text { per min. } \\
(\mathrm{mm} . \mathbf{H g} \\
\text { sec. cm. } .^{2} \\
\left.\text { min. } \times 10^{-3}\right)\end{array}$} & \multirow{2}{*}{$\begin{array}{c}\text { Ejection } \\
\text { time } \\
(\mathrm{sec} .)\end{array}$} & \multirow{2}{*}{$\begin{array}{l}\text { Mean } \\
\text { ejection } \\
\text { rate } \\
\text { (ml./sec.) }\end{array}$} & \multicolumn{2}{|c|}{$\begin{array}{l}\text { Mean circumferential } \\
\text { shortening rate }\end{array}$} \\
\hline & & & & & & & & & (cm./sec.) & $\begin{array}{c}\text { (circum- } \\
\text { ferences/ } \\
\text { sec.) }\end{array}$ \\
\hline $\begin{array}{l}1 \\
2 \\
3 \\
4 \\
5 \\
6\end{array}$ & $\begin{array}{l}\text { Before } \\
\text { After } \\
\text { Before } \\
\text { After } \\
\text { Before } \\
\text { After } \\
\text { Before } \\
\text { Aftcr } \\
\text { Before } \\
\text { After } \\
\text { Before } \\
\text { After }\end{array}$ & $\begin{array}{l}0.430 \\
0.380 \\
0.410 \\
0.410 \\
0.365 \\
0.390 \\
0.395 \\
0.380 \\
0.365 \\
0.395 \\
0.390 \\
0.400\end{array}$ & $\begin{array}{l}125 \\
125 \\
135 \\
115 \\
180 \\
170 \\
155 \\
160 \\
175 \\
170 \\
120 \\
130\end{array}$ & $\begin{array}{l}4300 \\
4200 \\
3700 \\
3800 \\
5300 \\
5500 \\
5000 \\
5700 \\
6300 \\
5800 \\
3400 \\
4200\end{array}$ & $\begin{array}{l}4200 \\
3300 \\
5300 \\
4300 \\
6200 \\
5500 \\
4100 \\
4500 \\
5500 \\
5100 \\
5900 \\
5500\end{array}$ & $\begin{array}{l}145 \\
120 \\
145 \\
140 \\
184 \\
178 \\
131 \\
161 \\
197 \\
175 \\
166 \\
178\end{array}$ & $\begin{array}{l}0.300 \\
0.310 \\
0.280 \\
0.280 \\
0.285 \\
0.300 \\
0.295 \\
0.275 \\
0.290 \\
0.295 \\
0.285 \\
0.280\end{array}$ & $\begin{array}{l}150 \\
100 \\
155 \\
130 \\
290 \\
230 \\
140 \\
130 \\
165 \\
140 \\
265 \\
195\end{array}$ & $\begin{array}{l}7 \cdot 3 \\
5 \cdot 6 \\
6 \cdot 5 \\
5 \cdot 8 \\
6 \cdot 6 \\
5 \cdot 6 \\
8 \cdot 2 \\
7 \cdot 2 \\
8 \cdot 3 \\
7 \cdot 4 \\
8 \cdot 3 \\
7 \cdot 1\end{array}$ & $\begin{array}{l}0.35 \\
0.30 \\
0.29 \\
0.27 \\
0.32 \\
0.28 \\
0.45 \\
0.38 \\
0.42 \\
0.38 \\
0.32 \\
0.28\end{array}$ \\
\hline Mean & $\begin{array}{l}\text { Before } \\
\text { After }\end{array}$ & $\begin{array}{l}0.41 \\
0.41\end{array}$ & $\begin{array}{l}150 \\
145\end{array}$ & $\begin{array}{l}4700 \\
4900\end{array}$ & $\begin{array}{l}5200 \\
4700\end{array}$ & $\begin{array}{l}161 \\
159\end{array}$ & $\begin{array}{l}0.31 \\
0.31\end{array}$ & $\begin{array}{l}195 \\
155\end{array}$ & $\begin{array}{l}7.5 \\
6.4\end{array}$ & $\begin{array}{l}0.36 \\
0 \cdot 32\end{array}$ \\
\hline
\end{tabular}



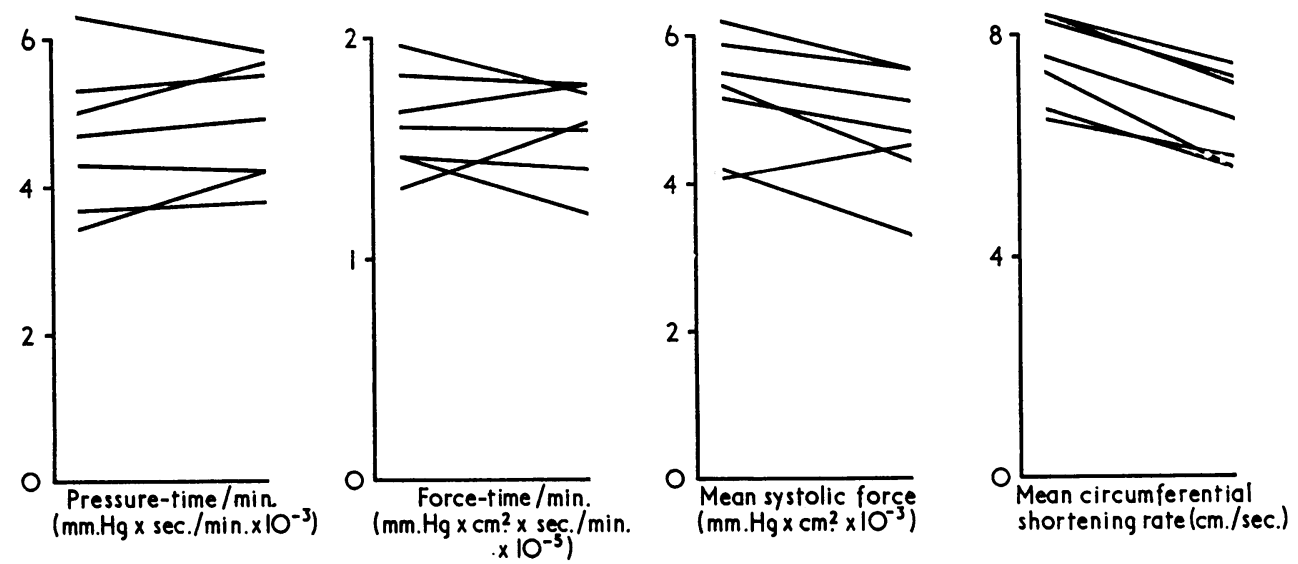

Fig. 2.-The effect of propranolol $5 \mathrm{mg}$. and atropine $2.4 \mathrm{mg}$. on three indices of left ventricular wall force and on the mean circumferential shortening rate. There is little change in the force measurements, but the consistent fall in mean circumferential shortening rate indicates a reduction in the velocity of contraction of the muscle fibres in the left ventricular wall.

thermodilution ratios corrected to 2 significant figures were used in the subsequent calculations. Calculated left ventricular end-diastolic volume, derived from the thermodilution ratio and the stroke volume measurement, showed no consistent change.

Mean systolic force, which depends on pressure and volume, fell from 5200 to $4700 \mathrm{~cm} .^{2} \mathrm{~mm}$. $\mathrm{Hg}$ on average, but the value increased in one patient and the changes were not significant (Table IV and Fig. 2). Force-time per minute, which takes heart rate and the duration of systole into consideration, showed no consistent change. Measurement of the mean circumferential shortening rate showed a consistent and significant fall, from 7.5 to $6.4 \mathrm{~cm}$./ sec. $(p<0.001 \mathrm{~cm} . / \mathrm{sec}$.$) , largely related to the re-$ duction in stroke volume. These findings are similar when the results are expressed in terms of mean ventricular circumference.

\section{Discussion}

A clear step-wise increase in temperature was evident in all the thermodilution curves used in the present study. Systematic analysis of thermodilution curves (Hamer and Fleming, 1967) suggests that the technique gives a satisfactory estimate of left ventricular volume under the conditions of the present study. The close agreement between left ventricular diastolic volumes measured by this technique and by angiocardiography (Fleming and Hamer, 1968) gives further confidence in the validity of the method. Though there is considerable variation in the thermodilution ratio, the ability to carry out repeated estimates allows the demonstration of a consistent difference before and after the drugs, which in three cases reaches statistical significance. The pooled data show a very significant increase in the mean value after propranolol and atropine.

The alterations in thermodilution ratio indicate a lesser degree of emptying of the ventricle at each beat, which might be considered, in itself, an index of impaired contractility. As the combination of propranolol and atropine in our patients led to a reduction in cardiac output and stroke volume, little alteration is evident in the calculated end-diastolic volume of the left ventricle, which is derived from the stroke volume and the thermodilution ratio.

Measurement of the left ventricular volume is of importance in the assessment of myocardial performance, as changes in the size of the chamber indicate alterations in myocardial performance which are not evident from measurements of ventricular pressure and stroke volume. When ventricular volume measurements are available it is possible to calculate the force and velocity of contraction of the muscle in the ventricular wall. These measurements give a more complete picture of the behaviour of the heart muscle than other estimates of ventricular performance (Covell et al., 1966). The oxygen consumption of the myocardium is probably related to the force developed in the ventricular wall, the duration of the contraction, and the velocity of contraction of the muscle fibres (Sonnenblick et al., 1965), though the relative importance of each of these factors is not known at present. 
The thermodilution technique gives estimates of ventricular volume at the end of systole and at the end of diastole, so we can calculate only the mean force and velocity of contraction in the ventricular wall. We cannot take into consideration the effect of variations during the course of ventricular systole. We have also neglected the energy wasted, particularly in the early part of systole, in stretching the parts of the ventricular wall which are not capable of contraction. However, there is evidence that the effect of these non-contractile elements in the muscle fibres is not of major importance (Sonnenblick, 1965), and the calculations which have been proposed to take this effect into consideration involve only a relatively small correction to the force measurements (Britman and Levine, 1964). Our work is confined to patients with severe aortic stenosis, in which the left ventricle is operating against a fixed orifice resistance, so that any peripheral vascular changes will have little effect.

We have calculated three estimates of the force developed in the left ventricular wall (Table IV and Fig. 2). Pressure-time per minute is derived from the mean ventricular systolic pressure and the time occupied by systole; this index does not take ventricular volume changes into consideration. Mean systolic force is based on ventricular pressure and volume measurements, but does not involve measurement of the duration of contraction. Forcetime per minute combines these two measurements and takes into consideration ventricular pressure and volume as well as the time occupied by systole. The mean circumferential shortening rate is used as a measure of the velocity of contraction. No clear-cut choice can be made between these indices as estimates of myocardial oxygen consumption. There is a reciprocal relation between the force and the velocity of contraction of heart muscle, so clearly both aspects must be considered. However, the velocity of contraction is also affected by the duration of systole, i.e. a prolonged systole is necessarily associated with a slow contraction, and the net effect on oxygen consumption is not evident. It is not, therefore, possible to construct an over-all index of the energy used by the ventricle, and the changes in force and velocity of ventricular contraction must be considered separately.

Recent work has shown evidence of reduced ventricular contractility after vagal stimulation in animals (DeGeest et al., 1965; Daggett et al., 1967), but there is little evidence of such an effect in man. However, atrial contractility is under vagal control, and after atropine a greater atrial contraction may have an indirect effect on left ventricular work as a result of an increase in ventricular end-diastolic pressure. Atropine in the dose used here has been shown to produce almost complete vagal block (Chamberlain, Turner, and Sneddon, 1967), and the absence of any noticeable change in the height of the "a" wave in the left ventricular diastolic pressure in our patients suggests that an increase in atrial contractility from a reduction in vagal tone may counteract the adverse effect from propranolol noted in our previous work (Hamer and Fleming, 1967).

The net effect of atropine and propranolol on heart rate was to produce a slight tachycardia in all except one patient, who had a rapid initial heart rate. As there was little alteration in left ventricular systolic pressure or the duration of systole, pressure-time per minute did not change significantly. The changes in the systolic force in the ventricular wall, which are derived from both pressure and volume measurements, were not significant, though a tendency towards a lower value after the drugs is noticeable. When the effect of the changes in rate and duration of systole are taken into consideration and force-time per minute is calculated, no consistent trend is evident. Force-time per minute seems the most complete estimate of the aspect of myocardial consumption concerned with ventricular wall tension.

The velocity of contraction of the muscle fibres in the ventricular wall showed a consistent fall after atropine and propranolol. The reduction in mean ejection rate cannot, in itself, be taken as a definite indication of a lower velocity of contraction as left ventricular end-diastolic volume fell in most of our patients. Direction calculation of the mean circumferential shortening rate, however, shows a consistent and significant reduction after the drugs. As it seems likely that there will be little change in ventricular structure over a short period, the same fibres may be assumed to occupy a given circumference in the two parts of the study. If the findings are expressed as rate of change in circumference the same effects are evident, offering clear demonstration of a reduction in the velocity of shortening of the individual muscle fibres.

The changes in force and velocity after atropine and propranolol are similar to those which we have reported in other patients with aortic stenosis after propranolol alone (Hamer and Fleming, 1967). The findings are supported by the animal work of Whalen et al. (1968) who measured left ventricular volume by cine-angiocardiography in three dogs with surgically induced heart block. The rate was kept constant by pacing, and an increase in left ventricular volume was found after propranolol, though the presence of mitral incompetence in these dogs makes interpretation difficult. Indirect measurements of ventricular performance suggest a 
reduction in contractility after propranolol independent of a reduction in heart rate. Bloomfield and Sowton (1967) found a fall in cardiac output and ejection rate in paced patients with heart block, and Shinebourne (1969) showed a similar effect in exercising patients with hypertension at matched heart rates before and after beta-adrenergic blockade.

The reduced velocity of contraction in the absence of any alteration in ventricular wall force indicates a reduction in myocardial contractility. This effect, occurring with an increase in heart rate, cannot be secondary to the negative chronotropic effect of beta-adrenergic blockade, and provides convincing evidence of a negative inotropic effect of propranolol.

\section{SUMMARY}

The effect of $5 \mathrm{mg}$. propranolol on ventricular wall force and velocity of contraction has been studied in 6 patients with severe aortic stenosis at left heart catheterization. The fall in heart rate that is usually produced by propranolol was prevented by giving $2.4 \mathrm{mg}$. atropine. Force and velocity measurements were based on estimates of left ventricular end-systolic and end-diastolic volume using the thermodilution technique.

Stroke volume and left ventricular ejection rate fell consistently, but there was little change in left ventricular pressures. There was a significant increase in the thermodilution ratio, indicating less complete emptying of the ventricle at each beat, but there was no consistent change in left ventricular end-diastolic volume. Force measurements showed little alteration after propranolol and atropine, but there was a consistent and significant reduction in the mean circumferential shortening rate, indicating a reduction in the velocity of contraction in the left ventricular wall.

The demonstration that $5 \mathrm{mg}$. propranolol produces a reduced velocity of contraction when the fall in heart rate is prevented by atropine confirms that propranolol diminishes ventricular contractility by a mechanism independent of any reduction in heart rate.

\section{REFERENCES}

Bloomfield, D. A., and Sowton, E. (1967). Rate-independent effects of propranolol. Circulat. Res., 20 and 21, Suppl. III, p. 243.

Britman, N. A., and Levine, H. J. (1964). Contractile element work: a major determinant of myocardial oxygen consumption. F. clin. Invest., 43, 1397.

Chamberlain, D. A., Turner, P., and Sneddon, J. M. (1967). Effects of atropine on heart-rate in healthy man. Lancet, $2,12$.

Covell, J. W., Ross, J., Sonnenblick, E. H., and Braunwald, E. (1966). Comparison of the force-velocity relation and the ventricular function curve as measures of the contractile state of the intact heart. Circulat. Res., 19, 364.

Daggett, W. M., Nugent, G. C., Carr, P. W., Powers, P. C., and Harada, Y. (1967). Influence of vagal stimulation on ventricular contractility, $\mathrm{O}_{2}$ consumption, and coronary flow. Amer. F. Physiol., 212, 8.

DeGeest, H., Levy, M. N., Zieske, H., and Lipman, R. I. (1965). Depression of ventricular contractility by stimulation of the vagus nerves. Circulat. Res., 17, 222.

Fleming, J., and Hamer, J. (1968). Left ventricular volume in aortic stenosis measured by an angiocardiographic and a thermodilution method. Brit. Heart f., 30, 475.

Hamer, J., and Fleming, J. (1967). Effect of propranolol on left ventricular work in aortic stenosis. Brit. Heart $\mathcal{F}$., 29, 871.

Sarnoff, S. J., Braunwald, E., Welch, G. H., Case, R. B., Stainsby, W. N., and Macruz, R. (1958). Hemodynamic determinants of oxygen consumption of the heart with special reference to the tension-time index. Amer. F. Physiol., 192, 148.

Shinebourne, E. (1969). Evidence that the effect of betaadrenergic blockade on the haemodynamic response of hypertensive patients to exercise is not solely ratedependent. Cardiovasc. Res., 3, 52.

—, Fleming, J., and Hamer, J. (1967). Calibration of indicator dilution curves in man by the dynamic method. Brit. Heart f., 29, 920.

Sonnenblick, E. H. (1965). Instantaneous force-velocitylength determinants in the contraction of heart muscle. Circulat. Res., 16, 441.

—, Ross, J., Covell, J. W., Kaiser, G., and Braunwald, E. (1965). Velocity of contraction: a major determinant of myocardial oxygen consumption. f. clin. Invest., 44, 1099.

Watson, B. W., and Fleming, J. S. (1968). Left ventricular volume estimation in man using a thermocouple in the ascending aorta. Med. biol. Engng, 6, 399.

Whalen, R. E., Morris, J. J., Behar, V. S., and McIntosh, H. D. (1968). Hemodynamic effects of beta-adrenergic blockade at controlled ventricular rates. Amer. Heart f., 76, 775. 